\title{
Sociodemographic and anthropometric risk factors for type 2 diabetes (T2D) in Nador population
}

\author{
Ikram KENFAOUI ${ }^{1 *}$, Souad HAMMOUTOU Hamza EL AZHARI, Aymane KHAILI, Mohammed OUHSSINE \\ ${ }^{1}$ Natural Resources and Sustainable Development Laboratory. Faculty of Science BP 133. Ibn Tofaïl University. 14000, Kenitra , \\ Morocco.
}

\section{Corresponding author email: kenfaoui.sadiki@hmail.com}

\begin{abstract}
Populations with Type 2 diabetes are exposed to many complications that are due to complex mechanisms combining hyperglycemia, insulin resistance, low-intensity inflammation and accelerated atherogenesis. Cardio-cerebrovascular complications affect the prognosis of diabetes. This study aims to identify sociodemographic and anthropometric risk factors for type 2 diabetes in the population of Nador located in the north of Morocco. This epidemiological study took place in a private medical analysis laboratory in the city of NADOR for a period of one year extending from 01/10/2018 to 01/10/2019. It focused on 830 male and female subjects over the age of 18, all residing in the city of NADOR. The subjects' blood sugar levels were above $1.26 \mathrm{~g} / \mathrm{L}$, with the help of the laboratory reception and collection team of three secretaries and two nurses; we explained the purpose of the study to the population studied. Volunteers signed the consent form and then were interviewed using questionnaires; anthropometric measurements were taken in the sample collection room. Their confidentiality and privacy were respected. This study allowed us to shed light on certain socio-demographic and anthropometric characteristics as well as the problems from which the diabetic population suffers. The study found that female sex and old age are socio-demographic risk factors; it also found that waist circumference and BMI (body mass index) are anthropometric risk factors for T2D.
\end{abstract}

Keywords: diabetes, type 2 diabetes, blood sugar, socio-demographic risks, anthropometric risks.

\section{Introduction}

Diabetes is a real public health problem because of its increased prevalence and its socio-economic impact [1]. It is one of the most critical pathologies in both industrialized and developing countries [2].

According to the World Health Organization (WHO), the term "diabetes" is defined as a metabolic disorder with multiple etiology, characterized by chronic hyperglycemia accompanied by disturbances in the metabolism of carbohydrates, lipids and proteins due to disorders in the secretion and/or action of insulin (insulin resistance) $[3,4]$.

There are three main forms of diabetes: type 1 diabetes, type 2 diabetes and gestational diabetes. [5] Type 2 diabetes accounts for the vast majority of diabetes cases worldwide. It is usually the result of poor diet, overweight and lack of physical activity, which causes overweight and obesity [6].

Type 2 diabetes, which is non-insulin dependent, is the result of the body's inability to respond properly to the action of insulin produced by the pancreas. It causes long-term damage, dysfunction and deficiencies of various organs [7].
As Morocco is in the midst of demographic, nutritional and epidemiological transition [8, 9], DT2 is considered a century-old evil; metabolic disease linked to lifestyle and eating habit changes over the past 30 years $[10,11]$.

The main objective of this study is to determine the sociodemographic and anthropometric risk factors of DT2 in a population of NADOR in the North of Morocco.

\section{Materials and Methods}

Our epidemiological study took place in a private medical laboratory in the city of NADOR over a oneyear period from $01 / 10 / 2018$ to $01 / 10 / 2019$. It was focused on 830 male and female subjects over18 years old who reside in the city of NADOR.

We first applied for an internship with a private medical laboratory in the city of Nador, after obtaining the agreement, we explained to thephysician-biologist the purpose of the study. The subjects enlisted are patients with type 2 diabetes who came to check their blood sugar in the laboratory. 
Their blood glucose levels were above $1.26 \mathrm{~g} / \mathrm{l}$, with the help of the laboratory reception and sample collection team consisting of three secretaries and two nurses, we explained the purpose of the study to the patients, some agreed to volunteer and signed the consent form. The volunteers were surveyed using questionnaires; anthropometric measurements were taken in the sample collection room. Their confidentiality and privacy were respected.

\subsection{Inclusion criteria}

$\checkmark$ All patients with Type 2 diabetes, with or without degenerative complications and regardless of the age of diabetes.

$\checkmark$ Patients over 18 years.

$\checkmark$ Both sexes (Men and Women).

$\checkmark$ Patients living in the city in the city of NADOR.

\subsection{Exclusion criteria}

$\checkmark$ Pregnant women.

$\checkmark$ Breastfeeding women.

$\checkmark$ Children.

$\checkmark \quad$ Patients with type 1 and DG diabetes.

$\checkmark$ Non-residents in Nador.

We collected socio-demographic information: age, marital status, education and employment of the 830 subjects, we also used materials to make necessary anthropometric measurements.

For Weight Measurement we used a mechanical scale branded "SECA", the patient gets upright, motionless, barefoot and in light clothing.

The measurement of the waist is done with a fixed wall chart; the person to be measured stands barefoot, heels joined, legs straight, shoulders and arms relaxed. The back of his head, his shoulder blades, his buttocks, his calves and his heels must all touch.

The Body Mass Index (BMI) was calculated to assess the degree of obesity for each type 2 diabetic patient at admission. It is calculated according to the formula: IMC-Weight/Size 2 the result is expressed in $\mathrm{Kg} / \mathrm{m} 2$.

The waistcircumferencewas measured using a doublesided meter tape (seamstress meter). The person to be measured stands with his feet slightly apart, legs straight, shoulders and arms relaxed. We ask him to breathe calmly. For waist circumference, WHO recommends measuring at mid-distance between the iliac ridge and the last rib at the end of an exhalation. [10].

\subsection{Entering and analyzing the results}

The collected data was entered on Excel, after filtration and coding we transmitted them on a statistical operating medium SPSS version 23.0. The results are then expressed as averages \pm standard deviation, or as frequencies and percentages. The 5\% error hypothesis tests applied to compare averages and proportions are respectively Student Test and Khi-2 Independence Test.

\section{Results and Discussions}

\subsection{Socio-demographic parameters of the population} (Table1)

A total of 830 subjects participated in the study, of which $27.2 \%$ of men and $72.8 \%$ are women; the average age of the population is $59.06 \pm 14.51$ years with a predominance of the age group [55-70] years (44\%). Women are predominant than men in the same age group [55-70].

Table 1: Population Description according to Sociodemographic Parameters

\begin{tabular}{|l|c|c|c|c|c|}
\hline \multirow{2}{*}{} & \multicolumn{2}{|c|}{ Women (72.8\%) } & \multicolumn{2}{c|}{ Men (27.2\%) } & \multirow{2}{*}{ Test Khi-2 } \\
\cline { 2 - 4 } & frequency & number & frequency & number & \\
\hline
\end{tabular}




\begin{tabular}{|c|c|c|c|c|c|c|}
\hline $\begin{array}{l}\text { Age range } \\
\text { (Years): }\end{array}$ & $\begin{array}{l}{[18-25]} \\
{[25-40]} \\
{[40-55]} \\
{[55-70]} \\
>70\end{array}$ & $\begin{array}{r}1,8 \\
4,9 \\
18,1 \\
33,6 \\
14,5\end{array}$ & $\begin{array}{r}15 \\
41 \\
150 \\
279 \\
120\end{array}$ & $\begin{array}{c}0,7 \\
3,7 \\
6 \\
10,4 \\
6,3\end{array}$ & $\begin{array}{l}6 \\
31 \\
50 \\
86 \\
52\end{array}$ & 0,012 \\
\hline Educational & $\begin{array}{l}\text { level } \\
\text { illiteracy } \\
\text { primary } \\
\text { secondary } \\
\text { graduate }\end{array}$ & $\begin{array}{l}62,8 \\
3,5 \\
2,4 \\
4,2\end{array}$ & $\begin{array}{l}521 \\
29 \\
20 \\
35\end{array}$ & $\begin{array}{c}2,14 \\
0,7 \\
1,9 \\
3\end{array}$ & $\begin{array}{c}178 \\
6 \\
16 \\
25\end{array}$ & 0,002 \\
\hline employment: & $\begin{array}{l}\text { without } \\
\text { with }\end{array}$ & $\begin{array}{r}68 \\
4,9\end{array}$ & $\begin{array}{l}564 \\
41\end{array}$ & $\begin{array}{l}22,2 \\
4,9\end{array}$ & $\begin{array}{l}184 \\
41\end{array}$ & $<0.001$ \\
\hline Marital status: & $\begin{array}{l}\text { bachelor } \\
\text { divorced } \\
\text { married } \\
\text { widower }\end{array}$ & $\begin{array}{c}3 \\
1,4 \\
64,7 \\
3,7\end{array}$ & $\begin{array}{c}25 \\
12 \\
537 \\
31\end{array}$ & $\begin{array}{c}1,4 \\
1,3 \\
21,7 \\
2,7\end{array}$ & $\begin{array}{c}12 \\
11 \\
180 \\
22\end{array}$ & 0,006 \\
\hline
\end{tabular}

\subsection{Anthropometric Population Parameters (Table2)}

Table 2: Population Description according to Anthropometric Parameters

\begin{tabular}{|c|c|c|c|c|c|}
\hline & \multicolumn{2}{|c|}{ Women $(72.8 \%)$} & \multicolumn{2}{|c|}{ Men $(27.2 \%)$} & \multirow[t]{2}{*}{$\mathbf{P}$} \\
\hline & number & frequency & number & frequency & \\
\hline Weight (Kg) & \multicolumn{2}{|c|}{$79.8 \pm 15.45$} & \multicolumn{2}{|c|}{$81.25 \pm 13.68$} & 0,209 \\
\hline Waist circumference (cm) & \multicolumn{2}{|c|}{$92.38 \pm 13.4$} & \multicolumn{2}{|c|}{$101.0 \pm 10.34$} & $<0.001$ \\
\hline Size (Cm) & \multicolumn{2}{|c|}{$167.7 \pm 10.67$} & \multicolumn{2}{|c|}{$162.85 \pm 11.05$} & 0,467 \\
\hline \multicolumn{6}{|l|}{ BMI by degree: } \\
\hline Thinness $<18.5$ & 20 & 2,4 & 3 & 0,4 & \\
\hline Normal weight [18.5-24.9] & 119 & 14,4 & 62 & 7,5 & \\
\hline Overweight [25-29.9] & 157 & 19,1 & 68 & 8,3 & \\
\hline Obesity Class 1[30-34.9] & 141 & 17,1 & 52 & 6,3 & \\
\hline Obesity Class 2[35-39.9] & 106 & 12,9 & 25 & 3 & 0,014 \\
\hline Obesity Class $3>\mathbf{4 0}$ & 57 & 6,9 & 14 & 1,7 & \\
\hline
\end{tabular}

\section{BMI: Body Mass Index}

We studied patients with type 2 diabetes consulting the private laboratory since it is the most common form of diabetes.The average age of the population is $59.06 \pm 14.51$ years (Extremes of age are 18 years and 97 years) this result is consistent with the literature is due to the continued progression of T2D in Morocco, itself the result of several factors: increased sedentary 
lifestyles, obesity, population growth, improved public health and longer life expectancy. [12, 13].

The female predominance in our study ( $72.8 \%$ of cases) is explained by the regularity of consultations observed in women with diabetes, their concern to balance their diabetes, [14]butit is also due to the prevalence of obesity among the female population $(30.47 \pm 6.9)$ which is consistent with the incidence of morbid obesity of the national survey on Anthropometry conducted by the Office of the High Commissioner for Planning in 2015, ( $26.8 \%$ of women versus $8.2 \%$ obese men).

Illiteracy was found at a very high rate in the total population $(84.2 \%)$, this could be explained by the fact that our study population was predominantly made up of female and elderly individuals [15].

Occupational inactivity was also very marked in the overall workforce $(90.1 \%)$ this is due to the majority of housewives and the elderly who are retired.

The average BMI was $30.47 \pm 6.9 \mathrm{~kg} / \mathrm{m} 2$ for women and $29.20 \pm 6.18 \mathrm{~kg} / \mathrm{m} 2$ for men. The average waist circumference was $92.38 \pm 13.4 \mathrm{~cm}$ for women and $101.03 \pm 10.34 \mathrm{~cm}$.

For men Waist circumference (WC) is a marker of abdominal visceral adiposity and differentiates gynoid obesity from android obesity, the latter with an increased risk of hypertension, T2D and cardiovascular disease (CVD) [16].

BMI is the result of a calculation based on an individual's height and weight; it does not take into account adipose tissue place. Contrariwise, waist circumference measurements measure visceral adipose tissue that is harmful because it increases the risk of diabetes and cardiovascular complications [17].

It is confirmed by all cohort studies that obesity decreases the variability of insulin action and that beyond a BMI of $30-35 \mathrm{~kg} / \mathrm{m} 2$, effectively all individuals develop a certain degree of insulin resistance [18].

\section{Conclusion}

This study allowed us to identify certain sociodemographic and anthropometric characteristics and also allowed us to identify several problems from which this population suffers. Thus, the study shows that our diabetic studied population is aged $(59.06 \pm 14.51$ years); the extreme ages are 18 and 97 with heterogeneity characterized by:

- High illiteracy rate ( $84.79 \%$ female vs. $50 \%$ male),

- Sedentary living,

- Predominance of obesity in the female population $(36.9 \%$ of women $\mathrm{BMI}>30)$.

It emerges that at the end of this study, female sex, and advanced age are sociodemographic risk factors, in the other hand the Waist circumference and BMI are anthropometric risk factors for T2D.

In addition, more detailed studies are needed to take the various problems related to this age group of diabetics, in the Moroccan context, for better management of diabetes treatment in this elderly population.

\section{References}

[1].Massi-Benedetti.M, The cost of diabetes type II in Europe: the code2 Study. Diabetologia 45:S1-S4. Code-2 Advisory Board (2002)

[2] Farouqi. A, Prise en charge du diabète au Maroc: résultats de l'International Diabetes Management Practices Study (IDMPS), Vague 2, Médecine des maladies Métaboliques, Vol. 4, No6(Déc 2010)

[3] Observatoire Régional de la santé Réunion,Le diabète. Ile de La Réunion, ORS Réunion, France(2015)

[4] OMS, Diabète: action mondiale pour mettre un terme à la recrudescence du diabète et améliorer les soins(2016)

[5] Fédération Internationale du Diabète, ATLAS du DIABETE de la FID, 6éme édition(2013)

[6] Observatoire Régional de la santé Réunion, Le diabète. Ile de La Réunion, ORS Réunion, France(2015)

[7]Amuna. P, Zotor. FB; Epidemiological and nutrition transition in developing countries: impact on human health and development. Proc Nutr Soc67:82-90(2008)

[8] Arshag. D, Mooradian. MD, Sue McLaughlin, Cecilia Casey Boyer, and Jewel Winter. Diabetes Care for OlderAdults. 12(2):70-77(1999)

[9] Fédération Internationale du Diabète, ATLAS du DIABETE de la FID, 6éme édition (2013)

[10] OMS, Obésité : Prévention et prise en charge de l'épidémie mondiale, Genève(2003)

[11] Haute Autorité de Santé, Guide de parcours de soins: Diabète de type 2. Saint-Denis La Plaine: HAS (2014) 
[12] Gning. S, Thiam. M, fall. F, Le diabète sucré en Afrique subsaharienne. Aspects épidémiologiques, difficultés de prise en charge. Med Trop 67:607-11(2007)

[13] Haut Commissaire au Plan, à l'occasion de la présentation des résultats de l'Enquête Nationale sur l'Anthropométrie (ENA, 2011)

[14] Fédération Internationale du Diabète, ATLAS du DIABETE de la FID, 6éme édition (2013)

[15] Direction de Lutte Contre l'Analphabétisme, Rapport National du Royaume du Maroc, Tendances récentes et situation actuelle de l'éducation et de la formation des adultes (2008)
[16] Ordre professionnel des diététistes du Québec, Obésité et contrôle du poids. Manuel de nutrition clinique (Québec, 2000)

[17] Pouliot. MC, Després. JP, Lemieux. S, Moorjani. S, Bouchard. C, Tremblay.A, Nadeau. A, Lupien. PJ, Waist circumference and abdominal sagittal diameter: best simple anthropometric indexes of abdominal visceral adipose tissue accumulation and related cardiovascular risk in men and women.Am J Cardiol. Mar 1, 73(7):460-8(1994)

[18] Féry. F, Paquot. N, Etiopathogénie et physiopathologie $d u$ diabète de type 2 , Rev Med Liege , 60 : 5-6 : 361-368. (2005) 